\title{
THE INFLUENCE OF HEDONIC VALUE AND UTILITARIAN VALUE ON BRAND TRUST AND LOYALTY
}

\author{
Gusti Noorlitaria Achmad ${ }^{1}$, Syarifah Hudayah ${ }^{2}$, Zainal Ilmi $^{3}$ \\ Faculty of Economics and Business Mulawarman University ${ }^{1,2,3}$ \\ Email: gusti.noorlitaria.achmad@feb.unmul.ac.id, syarifah.hudayah@feb.unmul.ac.id, \\ zainal.ilmi@feb.unmul.ac.id
}

\begin{abstract}
This study aims to examine and analyze the influence of Hedonic Value and Utilitarian Value on Brand Trust and loyalty on shoe products. This research will be conducted by distributing questionnaires to 100 respondents who use shoe products. The analysis technique used is quantitative analysis techniques with path analysis methods. The results of this study indicate that the hedonic value has a significant positive effect on brand trust. Utilitarian values do not have a significant influence on brand trust. Brand trust has a significant positive effect on Loyalty.
\end{abstract}

Keywords: $\quad$ Hedonic Value, Utilitarian Value, Brand Trust, Loyalty

\section{Preliminary}

Along with the development of the Age, footwear that protect all parts of the foot called the shoe has become an inseparable part of today's life, especially the urban community. Not infrequently people prefer to travel with shoes than sandals. In the past shoes were only used for formal purposes but now many shoe models have been made for casual purposes (Ramadhan

a, 2015).

Shoes themselves have existed since the Ice Age, about 5 million years ago. But at that time, shoes were only wrapped in a piece of cloth or made of animal skin. Now, with the advancement of trends and technology there have been established many factories to produce shoes with various models that suit their needs.

In the era of free trade, every company faces intense competition, not only large companies but also small companies also experience competition. Consumer trust in brands can be created if producers can create good relationships with consumers. To create loyalty, producers must be able to create consumer trust in a brand, because consumer loyalty to the brand cannot be known without the consumer's trust in the brand.

If the customer is loyal to a brand, then it is likely that the customer will continue to make purchases on the same brand continuously. The existence of customer loyalty to a brand can bring benefits to the company. That way, loyalty will become one of the goals that must be achieved by a company. With the success of natural companies to build customer loyalty, the company's survival will be maintained.

The purpose of this study is

1. to determine the effect of hedonic values on brand trust,

2. the influence of utilitarian values on brand trust,

3. influence of brand trust on loyalty. 
International Journal of Economics, Business and Accounting Research (IJEBAR)

Peer Reviewed - International Journal

Vol-4, Issue-3, 2020 (IJEBAR)

E-ISSN: 2614-1280 P-ISSN 2622-4771

https://jurnal.stie-aas.ac.id/index.php/IJEBAR

\section{References And Hypotheses}

Based on previous research conducted by Gary A. Tanojohardjo, Yohanes S. Kuanto, Ritzky K. Megah Roza Brahmana with the research title Hedonic Value and Utilitarian Value Analysis of Brand Trust with Brand Satisfaction as Intervening Variable in L'oreal Professionel Staining Products contained in in Petra Marketing Management Journal Vol. 2, No. 1 of 2014 states that the Hedonic Value has a significant positive effect on Brand Satisfaction.

In the title Relationships Among Utilitarians and Hedonic Values, Brand Affect and Brand Trust in The Smartphone Industry by Ikram Fatih Gecti published in Journal Management Research Vol.6, No. 2 of 2014 states that Utilitarian and Hedonic Value has a significant relationship with Brand Effects; Utilitarian Value has a positive influence related to Brand Trust; Hedonic value does not significantly influence Brand Trust; Brand effects have a significant effect on brand trust.

On the title Effect of Brand Trust and Brand Commitment on Brand Loyalty by Mirza Arief, Imam Suyadi, Sunarti published in the Business Administration Journal (JAB) Vol. 44, No. March 1, 2017 states that the Brand Trust and Brand Commitment variables have a significant effect on Brand Loyalty; Brand Trust has a positive and significant effect on Brand Loyalty; and Brand Commitment variable has a significant effect on Brand Loyalty.

In a study conducted by Wahyu Yuli Tri Bodro Sari, Srikandi Kumadji, Wasis A. Latif with the title Effect of Brand Trust on Brand Loyalty published in the Journal of Business Administration Vol. 5, No. 2 of 2013 states that there is a positive influence between the Brand Trust variables consisting of Brand Characteristics, Company Characteristics and Consumer-Brand Characteristics on the Brand Loyalty Level.

In the title of Consumers' Trust in a Brand and Link to Brand Loyalty by Geok Theng Lau, Sook Han Lee published in the Market Focus Management Journal in 1999 obtained the result that Trust in Brands was positively related to Brand Loyalty and a number of factors thought to influence Brand Trust includes Brand Characteristics, Company Characteristics, and Consumer-Brand Characteristics.

\section{Hedonic Value}

Hedonic values are based on a purchase motivation from consumers because consumers like it, driven by the desire to achieve a form of pleasure, freedom, delusion, and escape from problems. Hedonic consumption refers to the needs of consumers in using a product to create a sense of fantasy, produce feelings based on, senses, and produce emotional stimuli to satisfy themselves.

Hedonic value is an assessment of the quality of shopping seen in terms of enjoyment, the feeling of attraction due to the eyes (visual appeal) of a product and as an escape from reality (escapism). (Subagio, 2011).

Hedonic value (hedonic value) is the overall assessment of a consumer as a result of fulfilling pleasure based on the use of a product (Yistiani, Yasa, \& atmosphere, 2012).

The hedonic value of a product also greatly influences consumer behavior, especially regarding consumer emotions and feelings. In practice before using or buying something, consumers must first like the product, freedom in determining, expressing joy, feeling happiness, and will produce satisfaction (Chitturi, Raghunathan, \& Mahajan, 2008).

According to (Kim, 2006) there are six dimensions to measure a consumer's hedonic level, namely: adventure, social, gratification, ideas, roles, and value shopping:

a. Adventure shopping, consumers shop because of their experience and by shopping, consumers feel like they have their own world.

b. Social shopping, consumers assume that the pleasure in shopping will be more enjoyable if done together with family or friends.

c. Gratification shopping, shopping is an alternative to reduce stress, overcome bad problems, and a means to forget the problems being faced. 
International Journal of Economics, Business and Accounting Research (IJEBAR)

Peer Reviewed - International Journal

Vol-4, Issue-3, 2020 (IJEBAR)

E-ISSN: 2614-1280 P-ISSN 2622-4771

https://jurnal.stie-aas.ac.id/index.php/IJEBAR

d. Shopping ideas, consumers shop to follow new fashion trends and to see products or something new.

e. Role shopping, consumers prefer shopping for others rather than for themselves so consumers feel that shopping for other people is a fun thing to do.

f. Value shopping, consumers assume that shopping is a game when there is a bargain in prices, or when consumers are looking for shopping places that offer discounts, closeout, or low prices.

Hedonist consumption is one of the consumer behaviors that is related to aspects of fantasy and emotion in experiences that are based on various benefits such as pleasure when using products (Park \& Kim, 2006).

\section{Utilitarian Value}

Utilitarian value is the willingness in a person to study the motives for getting a quality product, and also efficient in time and energy (Subagio, 2011).

Utilitarian products are generally not related to feelings / conditions. The utilitarian aspect of consumer value plays a very important role in shaping customer satisfaction and behavioral intentions (Ryu, Han, \& Jang, 2010).

Utilitarian motives emphasize the value of spending that has benefits related to the task, reasonable, cautious, and efficiency of activities (Fallefi \& Siregar, 2018).

Indicators of utilitarian values include:

1. Cost Saving

2. Convenience

3. Affordability

4. Multiple benefits

From some of the above meanings, it can be concluded that the utilitarian value itself is explained as the use or benefit felt by someone when using a product (Somba, Sunaryo, \& Mugiono, 2018).

\section{Brand Trust}

Trust is the expectations of the parties in a transaction, and the risks associated with the estimates and behavior of those expectations (Lau \& Lee, 1999).

Trust is defined as the perception of reliability from the point of view of consumers based on experience or more on interactions characterized by meeting expectations and product performance and satisfaction (Tanojohardjo, Kunto, \& Brahmana, 2014).

Brand is a name or symbol used by companies to identify a product and distinguish it from other products so that it is easily recognized by consumers when they want to buy a product (Sangadji \& Sopiah, 2013).

Another understanding of a brand can be defined as a distinguished name or symbol (such as a logo, stamp, symbol, symbol, sign, slogan, words or packaging) to identify goods or services from the seller or brand holder (S.A., 2008).

Understanding the brand itself can be classified into six levels, namely:

1. Brand as an attribute; that is, a brand can remind someone of certain attributes.

2. Brand with benefits; that is, the brand is not just about attributes, it's also about benefits. Because when a customer buys a product, not only the attributes are bought but also the benefits. 
International Journal of Economics, Business and Accounting Research (IJEBAR)

Peer Reviewed - International Journal

Vol-4, Issue-3, 2020 (IJEBAR)

E-ISSN: 2614-1280 P-ISSN 2622-4771

https://jurnal.stie-aas.ac.id/index.php/IJEBAR

3. Brand as a value; that is, the brand represents something, not only about the value of the product but also the value of the brand holder and also the value of the customer. For example: Mercedes, which means high performance, safety and prestige.

4. Brand as culture; this means that in addition to representing a company brand, it also acts to represent a certain culture. For example: Mercedes represents German culture that is organized, efficient, and of high quality.

5. Brand as personality; the brand reflects a certain personality. For example: Mercedes reflects reasonable leaders.

6. Brand as user; The brand can indicate the type of consumer who buys or uses the product.

So, it can be concluded that the brand is the name of a symbol used by the company as a characteristic for the goods or services it produces to make it easier for consumers to distinguish it.

The selection of a stamp for a type of item needs to be thought about because it is clear that however small the brand or stamp or brand that we have chosen has an influence on the smooth sales (Alma, 2011). Giving the brand of these products must be careful not to deviate from the situation and the quality and capabilities of the company.

The selection of brand names must be done carefully, because however small the brand that has been chosen by the company of course it can affect the smooth sales. So that every company should be able to establish a brand that can give a positive impression while still paying attention to the conditions in choosing a brand, including:

1. Easy to remember, in brand selection it is better if the brand chosen is easy to remember by consumers, both from the words and pictures, so that consumers can easily or prospective consumers remember it.

2. Giving a positive impression, companies in giving a brand to a product are endeavored to be able to give a positive impression on the goods or services produced.

3. Appropriate for promotion, in addition to the two conditions above, it is better to choose a brand if used for promotion is very good. Brands with beautiful names and attractive images play an important role in promotion. So try to give the company a brand that is easy to remember so consumers can easily pronounce it and also remember it.

So from the explanation above, brand trust is defined as the willingness of customers to believe in a brand with all the risks that must be borne because expectations of the brand will lead to positive results.

Brand trust is the ability of a brand that is trusted by consumers that the product can meet the needs and interests of consumers.

Brand trust is the consumer's belief that in a product there are certain benefits, this belief arises because of repeated perceptions and the presence of learning and prior experience (Arief, Suyadi, \& Sunarti, 2017).

\section{Brand Loyalty}

Brand loyalty is consumer behavior in which customers show a consistent attitude towards a brand that is reflected in the repurchase of an item or service from a particular company.

Brand loyalty is a form of consumer loyalty to a brand that has been purchased and consumed. This loyalty is shown by whether or not a customer will switch to other brands offered by competitors, especially if the brand has changed (Arief et al., 2017).

(Chaudhuri \& Holbrook, 2001) defines brand trust as the willingness of the average consumer to depend on the ability of a brand to carry out all its uses or functions.

Loyalty includes the likelihood of ongoing purchases or the likelihood that customers will switch to other service providers or brands. Forming loyalty is one way to maintain the sustainability of the company, because the formation of loyal customers will benefit the company as a manufacturer. 
When individuals trust other parties in interpersonal relationships, individuals will hang themselves with other parties and individuals will have a commitment in the relationship. This commitment will make individuals have the intention to maintain the relationship. Likewise, if what is trusted is the Brand (brand), then the individual has the intention (intention) to maintain its relationship with the brand (Juari, 2010).

Loyalty can be interpreted as a deep commitment to repeat purchases of products or services consistently in the future with the same brand despite the situational influence and marketing efforts that can cause transitional behavior (Sari, Kumadji, \& Latief, 2013).

Customer loyalty is a very important element for every company. Because of customer loyalty can affect the survival of the company. Therefore, what must be considered by the company is not only how to maintain existing customers, but more important is how to make them loyal customers to the brand that the company produces.

Companies that have customers with high brand loyalty are very profitable for the company. Because it can reduce company marketing costs where the cost to retain customers is much cheaper than getting new customers (Riana, 2008).

\section{Research Methods}

On the basis of the description of the research, this type of research is exploratory research (explanatory research) using a quantitative approach. Population is a unit of individuals or subjects in a certain area and time that will be observed or examined. While the sample is a small part of the population taken to represent the population to be studied.

Based on this study because the population is not greater than 100 respondents, the authors take $100 \%$ of the total population. Data obtained through a questionnaire. Thus, the use of an entire population without having to draw research samples as observation units is called census techniques.

Measurement of variable indicators using a Likert scale, namely for the perception of "strongly agree" was given a score of 5, "agreed" was given a score of 4, "disagreed" was given a score of 3 , "disagreed" was given a score of 2, and "strongly disagreed" was given a score of 1 Each statement item will go through testing for validity and reliability in the research model.

Data analysis was performed through measurement of model constructs and relationships between

variables with the Pertial Least Square (PLS) technique.
The variables used in this study include free or exogenous variables (X) consisting of Hedonic Value (X1) and Utilitarian Value (X2), as well as bound or endogenous variables (Y) consisting of Brand Trust (Y1), and Loyalty ( Y2).

\section{Relationship Between Variables \\ Relationship between Hedonic Value and Brand Trust}

From previous research that discusses Relationships among hedonic and utilitarian values, satisfaction and behavioral intentions in the fast-casual restaurant industry (Ryu et al., 2010) shows the results that Hedonic Value does not have a significant influence on Brand Trust.

\section{Relationship between Utilitarian Values and Brand Trust}

Researchers who have previously discussed Relationships among hedonic and utilitarian values, satisfaction and behavioral intentions in the fast-casual restaurant industry (Ryu et al., 2010) found that Utilitarian Value has a positive influence on Brand Trust.

\section{The Relationship between Brand Trust and Loyalty}

From previous research conducted by (Arief et al., 2017) regarding the Effect of Brand Trust and Brand Commitment on Brand Loyalty shows the results that Brand Trust has a positive and significant effect on Brand Loyalty. In a study conducted by (Widodo \& Tresna, 2018) with the title The Influence of Brand Trust On Brand Loyalty, the results show that customer trust in a brand will affect the level of loyalty to the brand. So it can be concluded that brand trust has a significant effect on 
International Journal of Economics, Business and Accounting Research (IJEBAR)

Peer Reviewed - International Journal

Vol-4, Issue-3, 2020 (IJEBAR)

E-ISSN: 2614-1280 P-ISSN 2622-4771

https://jurnal.stie-aas.ac.id/index.php/IJEBAR

Brand Loyalty. And previous research on the Analysis of the Effect of Brand Image (Brand Image) and Brand Trust on Brand Loyalty (Brand Loyalty) of PT. Ades Alfindo Putra Setia (Bastian, 2014) obtained the results of which in this study, Brand Trust has a positive and significant influence on Brand Loyalty.

\section{Conceptual Framework}

Based on the description above, so that the research objectives can be achieved, then proposed 4 (four) research hypotheses, namely: (H1) Hedonic Value significantly positive effect on Brand Trust, $(\mathrm{H} 2)$ Utilitarian Value has a significant negative effect on Brand Trust, (H3) Brand Trust influences significant positive effect on Loyalty, and (H4) Brand Trust has a significant positive effect on attitude loyalty. The following conceptual framework of the variables and research hypotheses:

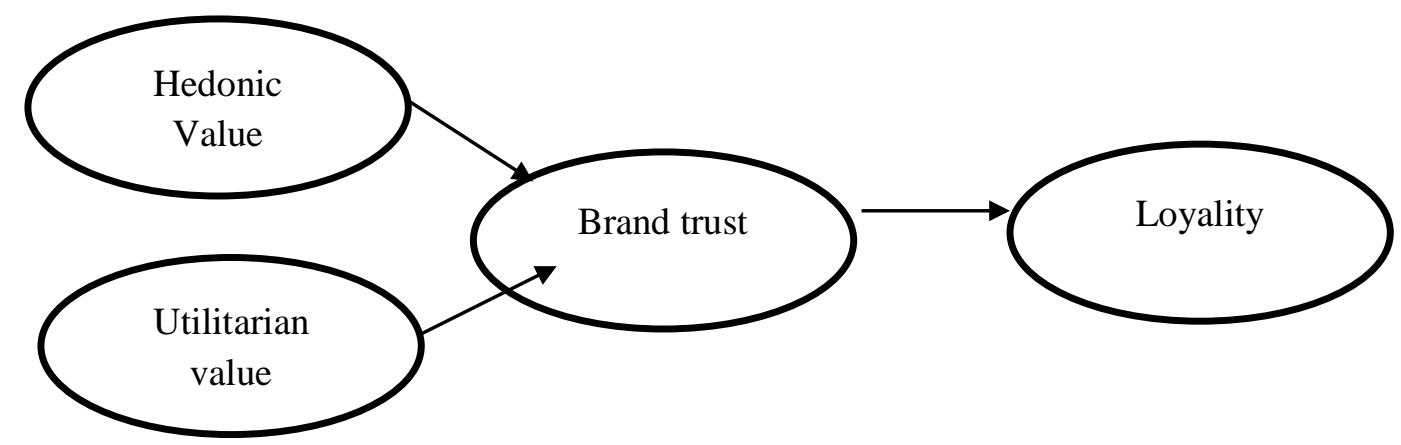

\section{Research Methods}

Based on the initial purpose of the study, which is to find out the effect of hedonic values and utilitarian values on brand loyalty through brand trust in shoes. The analysis includes:

1. Test Validity

Validity test is done to test whether the answers from respondents through the questionnaire are really valid or not. The validity of a data for each variable is shown in the Outer Loading value which is angka 0.70 .

2. Reliability Test

Reliability is the extent to which the accuracy, accuracy, or accuracy shown by the research instrument. The reliability test is conducted to find out whether the results of the answers of the respondents through a questionnaire are really stable in measuring symptoms or events. Reliability test is done by testing the value of Cronbach Alpha / CA (a). A variable is said to be reliable if it has a value of CA (a)>0.60.

3. Path Analysis

The research hypothesis testing was carried out using a path analysis model and data processing using the SmartPLS program. This path analysis was originally developed by Sewal Wright who developed the method as a tool to study the direct effects and indirect effects of a variable, where some variables are considered to be the cause of other variables.

\section{Results And Discussion}

Data that has been entered into the construct model on SmartPLS is then calculated (running) to find out its validity and reliability. This process can be repeated repeatedly until the loading factor results of all indicators are above the validity requirement of 0.70 . While indicators which have a loading factor value below 0.70 must be removed so that the validity and reliability of this model can be improved.

Hypotheses are tested based on the path coefficient (path coefficient), so that the significant influence between constructs is known, by looking at the value of the parameter coefficient and the tstatistic value (t-count). Testing is done in 2 (two) directions, with limitations to reject or accept the proposed hypothesis, using an $\alpha$ value of 5\%, and a T-table of 1.985 . If the T-statistic value is more 
International Journal of Economics, Business and Accounting Research (IJEBAR)

Peer Reviewed - International Journal

Vol-4, Issue-3, 2020 (IJEBAR)

E-ISSN: 2614-1280 P-ISSN 2622-4771

https://jurnal.stie-aas.ac.id/index.php/IJEBAR

than 1.985 , then the hypothesis proposed can be accepted, but if the T-statistic value is less than 1.985 , the hypothesis will be rejected.

\begin{tabular}{|c|c|c|c|c|c|}
\hline \multicolumn{6}{|c|}{ Koefisien Jalur } \\
\hline & $\begin{array}{c}\text { Original } \\
\text { Samples } \\
\text { (O) }\end{array}$ & $\begin{array}{c}\text { Sample } \\
\text { averages (M) }\end{array}$ & $\begin{array}{c}\text { Standard } \\
\text { Deviation } \\
\text { (STDEV) }\end{array}$ & $\begin{array}{c}\text { T Statistik( } \\
\text { O/STDEV) }\end{array}$ & Value \\
\hline $\begin{array}{c}\text { Hedonic Value } \\
\text { (X1) -> Brand } \\
\text { Trust (Y1) }\end{array}$ & 0,598 & 0,598 & 0,060 & 9,999 & 0.000 \\
\hline $\begin{array}{c}\text { Utilitarian Value } \\
\text { (X2) -> Brand } \\
\text { Trust (Y1) }\end{array}$ & 0,052 & 0,067 & 0,089 & 0,587 & 0.534 \\
\hline $\begin{array}{c}\text { Brand Trust (Y1) } \\
->\text { Loyalty (Y2) }\end{array}$ & 0,698 & 0,699 & 0,051 & 13,804 & 0.000 \\
\hline
\end{tabular}

Figure 3. Path Coefficient Calculation Results

The figure above shows that the Hedonic Value variable influences brand trust (0.598. T-statistics $=9,999>1,985)$. Utilitarian value has no effect on brand trust $(0.052$. T-statistics $=0.587<1.985)$.

Brand Belief Variables have direct effect on Loyalty (0.698. T-statistic 13.804> T-table 1.985).

R-Square inner model analysis is a goodness-fit test of the model, as in the following figure:

\begin{tabular}{|l|l|}
\hline \multicolumn{2}{|c|}{ R Square } \\
\hline Brand Trust (Y1) & R Square \\
\hline Loyalty (Y2) & 0,377 \\
\hline
\end{tabular}

Figure 4. R-Square Results Table for Smart-PLS calculations

From the table above obtained $\mathrm{R}$ Square for the Brand Confidence variable is 0.377 , which means $37.7 \%$ can be explained by the variable Hedonic Value and Utilitarian Value. R Square for the variable Loyalty is 0.487 which means that $48.7 \%$ can be explained by the variable Hedonic Value, Utilitarian Value and Brand Trust.

\section{Research Result}

a) Effect of Hedonic Value (X1) on Brand Trust (Y1)

From the results of data analysis in this study, it can be seen that the hedonic value variable (X1) has a significant influence on brand trust (Y1) of 0.598, T-statistic $=9,999>\mathrm{T}$-table 1,985 . This shows that $(\mathrm{H} 1)$ is accepted, meaning that there is a significant influence between the hedonic value variable (X1) on brand trust (Y1). This shows that the better the hedonic value of shoe products, the higher the level of brand trust in shoe products.

b) Effect of Utilitarian Value (X2) on Brand Trust (Y1)

From the results of data analysis in this study, it can be seen that the Utilitarian Value (X2) variable influences the Brand Trust (Y1) of 0.052, T-statistic $=0.587<\mathrm{T}$-table 1.985. This shows that (H2) is rejected, meaning that the Utilitarian Value (X2) has no direct effect on Brand Trust (Y1).

c) The Effect of Brand Trust (Y1) on Loyalty (Y2)

From the results of data analysis in this study, it can be seen that the brand trust variable (Y1) has a direct influence on buyer loyalty (Y2) of 0.698, T-statistics $=13,804>$ T-tables 1,985. This shows that (H3) is accepted, meaning that brand trust (Y1) has a direct and significant effect on Loyalty (Y2). This shows that the better the brand trust in the product, the higher the level of loyalty associated with purchases of shoes products. 
International Journal of Economics, Business and Accounting Research (IJEBAR)

Peer Reviewed - International Journal

Vol-4, Issue-3, 2020 (IJEBAR)

E-ISSN: 2614-1280 P-ISSN 2622-4771

https://jurnal.stie-aas.ac.id/index.php/IJEBAR

\section{Closing}

\section{Conclusion}

Based on the results of research on the Effect of Hedonic Value and Utilitarian Value on Brand Loyalty through Brand Trust in Shoes Shoe products obtained the following conclusions:

1. There is an influence between Hedonic Value (X1) on Brand Trust (Y1).

2. Utilitarian Value (X2) Has No Effect on Brand Trust (Y1)

3. There is an influence between Brand Trust (Y1) on Loyalty (Y2)

4. The coefficient of determination or R Square value of the Brand Trust variable (Y1) so that it can be interpreted that $37.7 \% \mathrm{~N}$ can be explained by the Hedonic Value variable (X1) and Utilitarian Value (X2).

5. The coefficient of determination or R Square from the variable Loyalty (Y2) so that it can be interpreted that $48.7 \%$ can be explained by the variable Hedonic Value (X1), Utilitarian Value (X2), and Brand Trust (Y1).

\section{Suggestion}

Based on the previous conclusions, the authors provide suggestions that might be used for companies in the future. Suggestions from the author, namely shoe products need to maintain and improve the function of the products they produce so that customers feel satisfied. By always paying attention to the use of the product in accordance with customer needs, the customer will give a positive value to the company because they are satisfied with what is given so that later it will affect the loyalty of the brand generated by the company. Customers who feel that what is provided exceeds what is expected, then the customer will feel satisfied and will likely use or buy back products with these brands for the long term.

\section{References}

Algesheimer, R., Dholakia, U. M., \& Herrmann, A. (2005). The Social Influence of Brand Community:Evidence from European Car Clubs. Journal of Marketing, 69(4), 19-34.

Alma, B. (2011). Manajemen Pemasaran Dan Pemasaran Jasa (9th ed.). Bandung: Alfabeta.

Arief, M., Suyadi, I., \& Sunarti. (2017). Pengaruh Kepercayaan Merek Dan Komitmen Merek Terhadap Loyalitas Merek (Survei pada Warga Kelurahan Penanggungan Konsumen Produk Aqua di Kota Malang). Jurnal Administrasi Bisnis, 44(1), 144-153.

Barus, Y. (2014). Sejarah Sepatu Produk sepatu. Kompasiana. Retrieved from https://www.kompasiana.com/yadibarus/5528a1fdf17e61bd6d8b45c8/sejarah-sepatu-produk sepatu

Bastian, D. A. (2014). Analisa Pengaruh Citra Merek (Brand Image) dan Kepercayaan Merek (Brand Trust) Terhadap Loyalitas Merek (Brand Loyalty) ADES PT. Ades Alfindo Putra Setia. Jurnal Manajemen Pemasaran Petra, 2(1), 1-9.

Chaudhuri, A., \& Holbrook, M. B. (2001). The Chain of Effects from Brand Trust and Brand Affect to Brand Performance: The Role of Brand Loyalty. Journal of Marketing, 65(2), 81-93.

Chitturi, R., Raghunathan, R., \& Mahajan, V. (2008). DELIGHT BY DESIGN: The Role of Hedonic Versus Utilitarian Benefits. Journal of Marketing, 72(3), 48-63.

Fallefi, M. R., \& Siregar, M. R. (2018). Pengaruh Nilai Utilitarian Dan Nilai Hedonis Terhadap Perpindahan Merek Dengan Kepuasan Konsumen Sebagai Pemoderasi (Studi Kasus Perpindahan Merek Dari Smartphone Lain Ke Iphone Pada Mahasiswa Di Lingkungan Universitas Syiah Kuala). Jurnal Ilmiah Mahasiswa Ekonomi Manajemen, 3(3), 143-154.

HANDAYANI, S. (2013). Analisa Loyalitas Pelanggan Yang Dipengaruhi Kepercayaan Merek Dan Kualitas Pelayanan (STUDI KASUS DI PT SPECTRA ADVERTAISING. Jurnal Ekonomi Manajemen Akuntansi, 20(35), 1-12.

Juari, R. (2010). Pengaruh Kepercayaan Merek Pada Pembentukan Loyalitas Merek APPLE Di YOGYAKARTA. Jurnal Bisnis Teori Dan Implementasi, 1(1), 63-89. 
International Journal of Economics, Business and Accounting Research (IJEBAR)

Peer Reviewed - International Journal

Vol-4, Issue-3, 2020 (IJEBAR)

E-ISSN: 2614-1280 P-ISSN 2622-4771

https://jurnal.stie-aas.ac.id/index.php/IJEBAR

Kiani, N. I. (2018). Hubungan antara nilai hedonis, nilai utilitarian, kepuasan konsumen, dan minat beli ulang di kafe kopi spesialti Kota Bandung. Industrial Reseacrh Workshop and National Seminar, 9 .

Kim, H.-S. (2006). Using Hedonic and Utilitarian Shopping Motivations to Profile Inner City Consumers. Journal of Shopping Center Research, 13(1), 57-79.

LAU, G. T., \& LEE, S. H. (1999). Consumers' Trust in a Brand and the Link to Brand Loyalty. Journal of Market Focused Management, 4, 341-370.

Park, C.-H., \& Kim, Y.-G. (2006). The Effect of Information Satisfaction and Relational Benefit on Consumers' Online Shopping Site Commitments. Journal of Electronic Commerce in Organizations, 4(1), 70-90.

Ramadhana, A. (2015). Sepatu sudah ada sejak Zaman Es, yaitu sekitar 5 juta tahun yang lalu. Brilio.Net. Retrieved from https://www.brilio.net/news/inilah-asal-usul-sepatu-yang-kamu-pakaisetiap-hari-1508038.html

Riana, G. (2008). Pengaruh Trust In A Brand Terhadap Brand Loyalty Pada Konsumen Air Minum AQUA Di Kota DENPASAR. Buletin StudiEkonomi, 13(2), 184-202.

Ryu, K., Han, H., \& Jang, S. (Shawn). (2010). Relationships among hedonic and utilitarian values, satisfaction and behavioral intentions in the fast-casual restaurant industry. International Journal of Contemporary Hospitality Management, 22(3), 416-432.

S.A., S. (2008). Dasar-Dasar Manajemen Merek (I; S. Wahyudi, Y. Setyorini, \& I. Basuki, eds.). Malang: Bayumedia Publishing.

Sangadji, E. M., \& Sopiah. (2013). Perilaku Konsumen (I; N. WK, ed.). Yogyakarta: ANDI.

Sari, W. Y. T. B., Kumadji, S., \& Latief, W. A. (2013). Pengaruh Kepercayaan Merek Terhadap Loyalitas Merek (Studi pada Mahasiswa SI Jurusan Ilmu Administrasi Bisnis Fakultas Ilmu Administrasi Universitas Brawijaya Tahun 2009/2010 Pengguna Handphone Nokia). Jurnal Administrasi Bisnis, 5(2), 1-7.

Somba, W. E., Sunaryo, \& Mugiono. (2018). Pengaruh Nilai Hedonis Dan Nilai Utilitarian Terhadap Behavioral Intention Dengan Word Of Mouth (Wom) Sebagai Variabel Mediasi. Jurnal Manajemen Dan Kewirausahaan, 6(1), 82-92.

Subagio, H. (2011). Pengaruh Atribut Supermarket Terhadap Motif Belanja Hedonik Motif Belanja Utilitarian Dan Loyalitas Konsumen. JURNAL MANAJEMEN PEMASARAN, 6(1), 8-21.

Tanojohardjo, G. A., Kunto, Y. S., \& Brahmana, R. K. M. R. (2014). Analisa Hedonic Value Dan Utilitarian Value Terhadap Brand Trust Dengan Brand Satisfaction Sebagai Variabel Intervening Pada Produk Pewarnaan L ORÉAL Professionnel. Jurnal Manajemen Pemasaran Petra, 2(1), 111.

Widodo, T. H., \& Tresna, P. W. (2018). The Influence Of Brand Trust On Brand Loyalty (Study on As Card Users in STIA YPPT Priatim Tasikmalaya). Jurnal Pemikiran Dan Penelitian Administrasi Bisnis Dan Kewirausahaan, 3(1), 81-88.

Yistiani, N. N. M., Yasa, N. N. K., \& Suasana, I. G. A. K. G. (2012). Pengaruh Atmosfer Gerai Dan Pelayanan Ritel Terhadap Nilai Hedonik Dan Pembelian Impulsif Pelanggan Matahari Department Store Duta Plaza Di Denpasar. Jurnal Manajemen, Strategi Bisnis, Dan Kewirausahaan, 6(2), 139-149. 